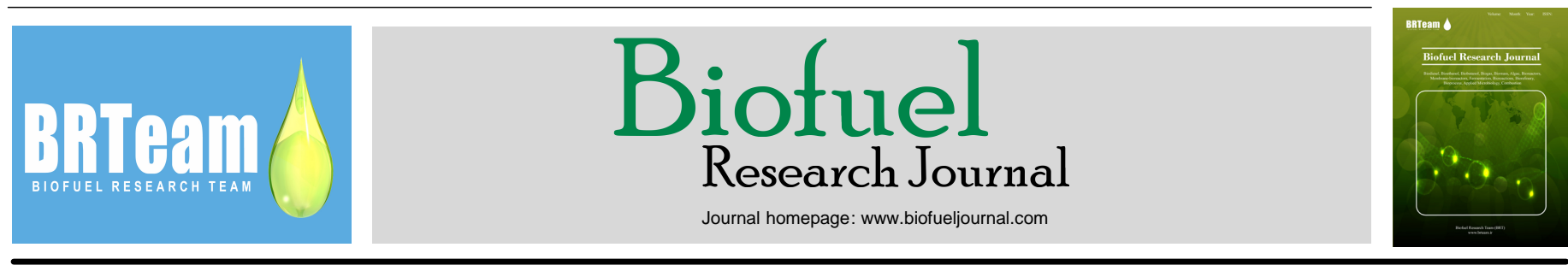

Original Research Paper

\title{
Biodiesel blend (B10) treated with a multifunctional additive (biocide) under simulated stored conditions: a field and lab scale monitoring
}

\author{
Adriane R. Zimmer ${ }^{1, *}$, Aline Oliboni ${ }^{1}$, Sergio L. C. Viscardi ${ }^{2}$, Roberta M. Teixeira ${ }^{2}$, Marco Flores Ferrão ${ }^{3}$, Fátima M. \\ Bento
}

${ }^{1}$ Universidade Federal do Rio Grande do Sul, Microbiology, Parasitology, and Immunology Departament, RS, Brazil.

${ }^{2}$ Universidade Federal do Rio Grande do Sul, Chemistry Departament, RS, Brazil.

${ }^{3}$ Ipiranga Produtos de Petróleo, Brazil.

\section{HIGHLIGHTS}

$\ddot{y}$ The additive including a biocide reduced biomass formation under both lab and field conditions.

ÿ The quality of B10 treated with MA-MBO50 remained within the standard specifications after $90 \mathrm{~d}$. $\ddot{y}$ Lab-scale data on the application of biocides need to be adjusted under real-world conditions.

\section{GRAPHICAL ABSTRACT}

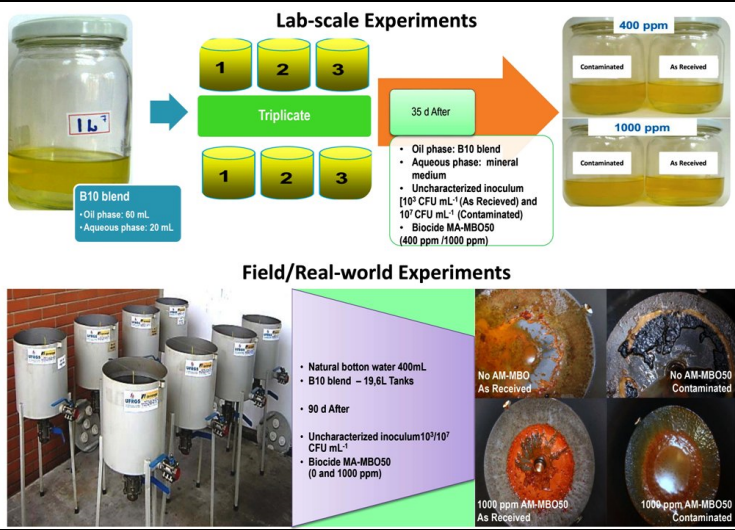

\section{ARTICLE INFO}

\section{Article history:}

Received 22 November 2016

Received in revised form 21 February 2017

Accepted 23 March 2017

Available online 1 June 2017

\section{Keywords:}

Biodiesel blend (B10)

Microbial growth

Multifunctional additive

Biocide

MBO

\begin{abstract}
Microbial contamination of stored diesel/biodiesel fuel over time and the consequent changes in the fuel chemical composition is of serious concern. The use of biocides has also been shown to be an effective strategy to address this challenge but in some countries like Brazil, no products have been released and licensed to be used yet. The aim of this study was to evaluate the effectiveness of a multifunctional additive containing a biocide (i.e., 3,3-methylenebis(5-methyloxazolidine); in short MBO) as $50 \%$ of its formulation (AM-MBO50) for controlling microbial contamination under simulated storage conditions. The experiment was conducted under two conditions: at lab-scale and in the field (real-world condition). In both experiments, B10 blend treated with AM-MBO50 as well as the untreated fuel blend were stored under simulated storage conditions for 35 and 90 $\mathrm{d}$, respectively. The additive effectiveness and the changes in oxidative stability, water content, density, and viscosity were monitored. The results showed that the evaluated product was an efficient treatment to control microbial growth at $1000 \mathrm{ppm}$ concentration, presenting a biocide action after $7 \mathrm{~d}$ in the tanks containing the treated fuel and with a low microbial challenge and a biostatic action in the tanks containing the treated fuel and with a high microbial challenge. In the tanks containing the fuel treated with AM-MBO50, no adhesion of biofilm in the oil/water interface nor meaningful changes in the quality parameters such as oxidative stability, water content, viscosity, and density were observed after $90 \mathrm{~d}$. A comparison between the lab-scale and field results showed that the application conditions determined at the lab-scale can only serve as preliminary guidance for the field (real-world) application and that they should be monitored and adjusted for each specific system.
\end{abstract}

(c) 2017 BRTeam. All rights reserved.

* Corresponding author at: Tel.: +55 519132 7474; Fax: +55 5133083665

E-mail address: bio_didi@yahoo.com.br; adrianezimmer@hotmail.com

Please cite this article as: Zimmer A.R., Oliboni A., Viscardi S.L.C., Teixeira R.M., Ferrão M.F., Bento F.M. Biodiesel blend (B10) treated with a multifunctional additive (biocide) under simulated stored conditions: a field and lab scale monitoring. Biofuel Research Journal 14 (2017) 627-636. DOI: 10.18331/BRJ2017.4.2.7 


\section{Introduction}

Microbial contamination in fuels has been reported since the beginning of the $20^{\text {th }}$ century and it is considered as one of the main problems related to the maintenance of the quality of stored fuels (Passman, 2013; Bücker et al., 2014; Soriano et al., 2015; de Azambuja et al., 2017). The impacts of such contaminations mainly depend on the fuel grade and storage time. On the other hand, the increasing global concerns about the environment and sustainability have led to an intense search for renewable and/or less harmful fuels. As part of this initiative, the diesel fuel formulation has changed over time, mainly by the reduction of sulfur and addition of biodiesel (Passman, 2013). However, the addition of biodiesel could increase the susceptibility of fuel blends to chemical and biological degradation (Dodos and Zannikos, 2013; Passman, 2013; Soriano et al., 2015). Consequently, there has been a recommendation to intensify some related procedures such as periodic draining and cleaning of storage tanks, and making the maintenance routines stricter. However, such practices are not always efficient due to the difficulty of properly draining the tanks (Hettige and Sheridan, 1989; Hill and Hill, 2000; Passman, 2013; Bücker et al., 2014). Under these situations, biocides can be used as a strategy to control microbial growth. However, most published data regarding biocides were obtained in laboratory experiments where controlled conditions may have overestimated the efficiency of the investigated products and therefore, their performance under real situations may have been predicted inaccurately (Hettige and Sheridan, 1989).

According to Passman (2013), biocides are restricted in their designated end-uses. Fuel treatment by biocides represents a tiny fraction $(<0.1 \%)$ of the total industrial microbicides market. However, the use of fuel-treatment microbicides is likely to increase. To get a registration for a new active ingredient in fuel, it is necessary to present product specifications and to obtain regulatory approvals. More specifically, some questions regarding the impacts of a given product on fuel grade, fuel to water ratio, aqueous phase chemistry, toxicity and emissions as well as fuel performance must be addressed (Passman, 2013). Regulations on biocide use may vary from country to country, but it is very important that tank owners/operators are familiar with the respective national and local regulations (Passman, 2013). In Brazil, the use of biocides is not a common practice and registration for their use must be handled by the Brazilian Institute of Environment (IBAMA) while authorization for their use in fuels must be granted by the National Petroleum Agency (ANP).

A biocide for fuels based on oxazolidine (i.e., 3,3-methylenebis(5methyloxazolidine); in short, $\mathrm{MBO}$ ) was registered by the US Environmental Protection Agency (EPA) and its use in Military Specification (MIL SPEC) was recently approved by the US military (Passman, 2013). Moreover, a multifunctional additive for fuels/biofuels containing 50\% active ingredient MBO (MA-MBO50) was investigated in our previous study with different approaches. Appropriate dosages were defined and the efficiency of the additive was tested under simulated storage conditions in flasks containing oil and mineral medium (Zimmer et al., 2010 and 2013; Bücker et al., 2014; Cazarolli et al., 2014). Accordingly, the aim of the present work was to assess the effectiveness of this multifunctional additive (i.e., MA-MBO50) in controlling microbial contamination of a B10 blend (10\% biodiesel and $90 \%$ diesel with $50 \mathrm{ppm}$ sulfur [LSD]), under simulated storage conditions in the field.

\section{Materials and Methods}

Two experiments were conducted to evaluate the effectiveness of the additive in controlling microbial contamination in fuel storage tanks. One experiment was performed in the laboratory (lab-scale; $250 \mathrm{~mL}$ microcosms) and the other in the field (field-scale; $20 \mathrm{~L}$ tanks) under real-world conditions.

\subsection{Fuel}

A B10 blend was prepared by mixing $90 \%$ diesel S50 (low sulfur: $50 \mathrm{ppm}$ ) and $10 \%$ pure biodiesel (B100) produced from $75 \%$ soybean oil and $25 \%$ tallow (v/v) provided by Ipiranga Petroleum Products S.A. (Brazil). The fuel used in both experiments was prepared at once with the assistance of the Ipiranga's technical team in Canoas, RS, Brazil. In both experiments, the fuel was used without sterilization, i.e., under the as received condition.

\subsection{Biocide: multifunctional additive containing $M B O(M A-M B O 50)$}

The additive possessed multiple functions to maintain fuel quality (diesel/biodiesel blend). The additive formulation included 50\% (v/v) MBO as active ingredient, a broad-spectrum biocide, soluble in oil and water capable of chemically controlling microbial contamination in fuels (Siegert, 2009; Passman, 2013). Two concentrations were tested in the lab-scale tests (400 ppm and $1000 \mathrm{ppm}(\mathrm{v} / \mathrm{v})$ ) while only $1000 \mathrm{ppm}$ was experimented under the field conditions. All tested concentrations were prepared in the fuel phase. Concentrations were selected based on previous lab-scale experiments performed in the LAB BIO UFRGS (Zimmer et al., 2010 and 2013) and following the manufacturer's recommendations. For clarity, AMMBO 50\% will be referred as AM-MBO50 throughout the text.

\subsection{Inoculum}

An uncharacterized inoculum was prepared as suggested in ASTM E1259-10. Briefly, an Erlenmeyer containing $100 \mathrm{~mL}$ of Bushnell-Haas broth (BH) (Bushnell and Hass, 1941) supplemented with 2\% diesel/biodiesel blends (sterile B10), was inoculated with $5 \mathrm{~mL}$ microbial sludge obtained from different fuels (diesel and diesel/biodiesel blends; B5) and the sample was incubated at $28^{\circ} \mathrm{C}, 100 \mathrm{rpm}$, for $7 \mathrm{~d}$. The inoculum was adjusted to a $0.5 \mathrm{McFarland}$ standard turbidity $(600 \mathrm{~nm})$ using the $\mathrm{BH}$ mineral medium in order to obtain approximately $10^{8} \mathrm{CFU} \mathrm{mL} \mathrm{m}^{-1}(\mathrm{CFU}=$ colony-forming units). Then, a 1:10 dilution was prepared with the $\mathrm{BH}$ mineral medium (lab-scale) or bottom water (field-scale) to obtain a final concentration of $10^{7} \mathrm{CFU} \mathrm{mL}^{-1}$ (Zimmer et al., 2013).

\subsection{Microbial challenge level}

The effectiveness of the additive as biocide was investigated at two microbial challenge levels: low, fuel as received (IP Standard 385 estimated at $10^{3} \mathrm{CFU} \mathrm{\textrm {mL } ^ { - 1 }}$ ); and high, with the addition of the microbial inoculum at a concentration of $10^{7} \mathrm{CFU} \mathrm{mL}^{-1}$ (Hill and Hill, 2009; Siegert, 2009).

\subsection{Lab-scale assay}

\subsubsection{Experimental design}

In this assay, the B10 blend treated with $400 \mathrm{ppm}$ or $1000 \mathrm{ppm}$ MAMBO50 was used as the oil phase. For the aqueous phase, sterile $\mathrm{BH}$ mineral medium was used (in $\mathrm{g} \mathrm{L}^{-1}: \mathrm{KH}_{2} \mathrm{PO}_{4}, 1.0 ; \mathrm{K}_{2} \mathrm{HPO}_{4}, 1.0 ; \mathrm{NH}_{4} \mathrm{NO}_{3}$, $1.0 ; \mathrm{MgSO}_{4} .7 \mathrm{H}_{2} \mathrm{O}, 0.2 ; \mathrm{FeCl}_{3}, 0.05 ; \mathrm{CaCl}_{2} .2 \mathrm{H}_{2} \mathrm{O}, 0.02$, pH 7.2 (BushnellHass, 1941) to provide inorganic support to the microorganisms (Hettige and Sheridan, 1989). The oil/water proportion in the system was $3: 1$ in order to provide minimum conditions for microbial growth within the microcosms. This proportion allowed a more accurate estimation of whether the inhibition of microbial growth was due to the use of the biocide and not by the limitations imposed by the microcosm (Raikos et al., 2012). Under this condition, two microbial challenge levels were evaluated: high

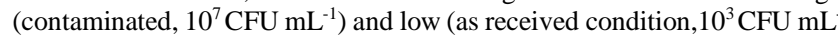
$\left.{ }^{1}\right)$.

To simulate fuel storage conditions, microcosms were made of $250 \mathrm{~mL}$ flasks containing $20 \mathrm{~mL}$ of $\mathrm{BH}$ mineral medium (sterile or contaminated with the inoculum) and $60 \mathrm{~mL}$ of B10 blend. All flasks were homogenized and kept in the dark in closed boxes at room temperature $\left(25 \pm 3^{\circ} \mathrm{C}\right)$ for 35 d. Destructive samples were prepared in triplicate at each sampling time $(0,7,14,21,28$, and $35 \mathrm{~d})$. Two controls were used: (a) aqueous phase and oil phase without inoculum or biocide; (b) aqueous phase and oil phase with inoculum and without biocide addition. At the end of each sampling, the following data were obtained in the aqueous phase: $\mathrm{pH}$, biocide effectiveness, type, and time of biocidal action over microbial population, and biomass (dry weight) formed after $35 \mathrm{~d}$ on the oil/water interface.

\subsection{Pilot assay: field-scale}

\subsubsection{Experimental design}

Experiments were conducted in eight $20 \mathrm{~L}$ tanks especially built of carbon steel and sand blasted with an iron shot. The tanks contained $19.6 \mathrm{~L}$ 
of B10 and $400 \mathrm{~mL}(2 \%)$ of natural bottom water ( $\mathrm{pH} 4.5)$ withdrawn from diesel S500 (sulfur 500 ppm) storage tanks (supplied by Ipiranga Petroleum Products S.A., Brazil). One set of four tanks received fuel (B10) treated with additive at $1000 \mathrm{ppm}$ and the other set received untreated fuel (controls). Natural bottom water $(400 \mathrm{~mL})$ was added to all tanks $24 \mathrm{~h}$ after treatment with the additive. Two tanks of each set received non-sterile natural bottom water (low-contamination level), and two received natural bottom water with

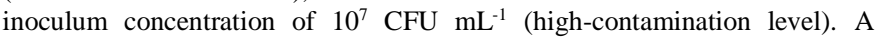
thermometer was placed at the center of each tank. The tanks were kept in a covered area protected from sunlight and rain. Samples were taken on days 0 , $7,14,21,28,60$, and 90. At each sampling time, the internal and external temperatures of each tank, relative humidity, and $\mathrm{pH}$ were recorded. Also, the time-kill was evaluated in the aqueous phase. The microbial growth (biomass) at the interface was estimated through measuring its dry weight after $90 \mathrm{~d}$.

Some chemical parameters were also evaluated in the oil phase following the ANP 04/2012 at time zero and after $90 \mathrm{~d}$ including water content (ASTM D6304), oxidative stability (EN 14112), viscosity (ASTM D446), and specific gravity (density, ASTM D4052). Sampling was carried out using sterile glass pipettes; $100 \mathrm{~mL}$ aliquots were taken from the oil phase from each tank, and placed in two different polyethylene tubes $(50 \mathrm{~mL})$ at each sampling time. The aqueous phase was removed and placed in $10 \mathrm{~mL}$ polyethylene tubes. All samples were stored at $4^{\circ} \mathrm{C}$ and transported to the laboratory for analysis.

\subsection{Analysis}

Fuel and water phases ad well as the interface were separately analyzed at each sampling time.

\subsubsection{Water phase}

$p H$ : the $\mathrm{pH}$ was measured using universal $\mathrm{pH}$ strips as the use of an electrode is not recommended when oil microdroplets are present in the aqueous phase.

Time-kill (lab-scale): the time needed for the biocide to stop the growth or to kill the microorganisms in the aqueous phase was assessed by monitoring the occurrence of culturable cells in the agar plates (nutrient agar for bacteria and malt agar for fungi, or Plate Count Agar (PCA) for total count Hymedia $^{\circledR}$ ). Briefly, an aliquot of $10 \mu \mathrm{L}$ of water was obtained from each microcosm and inoculated in plates containing solid media in order to neutralize the active ingredient, and incubated at $28^{\circ} \mathrm{C}$ for $2 \mathrm{~d}$ (bacteria), and up to $10 \mathrm{~d}$ (fungi). After this time, the presence or absence of microbial growth (biocide action) was identified. This test was performed in triplicate at each sampling time for all the replicates of each treatment.

Estimation of microbial count - CFU (field-scale): tenfold dilution was performed using sterile saline $(0.85 \%)$ and the samples were plated in triplicate in petri dishes containing Plate Count Agar (PCA). Plates were incubated at $28^{\circ} \mathrm{C}$ for $15 \mathrm{~d}$ and then $\mathrm{CFU}$ was counted. The average of the three replicates was calculated and expressed in logarithms.

\subsubsection{Interface}

Estimated biomass in the oil/water interface: the biomass formed in the oil/water interface was assessed by gravimetric measurements of cell dry weight $\left(\mathrm{mgL}^{-1}\right)$.

Microcosms (lab-scale): at the end of each sampling time, the total content of each flask was filtered through filter paper discs previously weighed. To remove excess oil from the biomass, $4 \mathrm{~mL}$ of hexane was added to each disk. The disks were placed in an oven at $30^{\circ} \mathrm{C}$ for $2 \mathrm{~d}$ to remove moisture and were then directly transferred to a desiccator until weighing.

Tanks (field-scale): after $90 \mathrm{~d}$, tank contents were thoroughly drained through a side drain until reaching the oil/water interface. Then, the remaining fuel and the water phase and the interface were drained into autoclaved flasks through a bottom drain, and transported to the laboratory. In the laboratory, the flask contents were filtered through a paper filter previously oven-dried and weighed. After filtering, $50 \mathrm{~mL}$ of hexane were added to the biomass to remove excess oil. Afterwards, filters were oven-dried at $30^{\circ} \mathrm{C}$ for $7 \mathrm{~d}$ and were then left in a desiccator for $48 \mathrm{~h}$ prior to weighing (Zimmer et al., 2013). Growth was calculated by monitoring the dry weight as a function of immersion time in aqueous systems/diesel oil, using the following formula:
Biomass variation $\left(m g L^{-1}\right)=[($ final weight $(\mathrm{mg})-$ start weight $(\mathrm{mg})) /$ water + fuel volume $(\mathrm{mL})] \times 1000$

\subsubsection{Oil phase}

Water content determination: to determine the dissolved water content, the Karl Fischer Coulometric method was applied following the ASTM D 6304 standard using an AMETROHM Karl Fischer titrator (KF 756) with a Mettler analytical scaleXP-205, $0.1 \mathrm{mg}$ resolution.

Determination of density: relative density at $20^{\circ} \mathrm{C}$ was determined based on the automatic method recommended by the ASTM D 4052, using a digital densimeter ANTON PAAR DMA 5000.

Determination of oxidative stability: accelerated oxidative stability tests were conducted according to the EN 14112 standard. Determination of oxidative stability (accelerated oxidation test) was performed using a Rancimat 873 METROHM

Determination of kinematic viscosity: kinematic viscosity measurements at $40^{\circ} \mathrm{C}$ were conducted using a set of Cannon Fenske viscometers, timers calibrated at $0.01 \mathrm{~s}$ resolution thermostatic bath, a thermometer calibrated with subdivision of $\pm 0.05^{\circ} \mathrm{C}$, and a manual vacuum pump. The ASTM D446-07 standard was used to determine the kinematic viscosity.

Only a single analysis for each chemical parameter was performed at each sampling time due to the large volume of fuel required for these analyzes.

Internal temperature of the tanks and relative humidity (field-scale): investigation of the internal temperature of the tanks was carried out with thermometers kept immersed in the oil phase at the center of each tank. For external temperature and relative humidity, a thermo-hygrometer was used.

\subsection{Statistical analysis}

Data were analyzed using the Tukey test (comparison of means) with a 95\% confidence level using Biostat (version 5.3).

\section{Results and Discussion}

The effectiveness of the multifunctional additive formulation with antimicrobial activity was evaluated under simulated storage conditions at lab-scale $(250 \mathrm{~mL}$ microcosms $)$ and field-scale $(20 \mathrm{~L}$ tanks) using an uncharacterized microbial consortium as suggested by the ASTM E125910 .

\subsection{Lab-scale}

In this study, no significant changes were observed in $\mathrm{pH}$ (aqueous phase: synthetic $\mathrm{BH}$ medium) and the $\mathrm{pH}$ remained in the range of 7 until the end of the 35-d experiment in all treatments. It has been frequently reported that biodiesel fraction of blends could be degraded in contact with water producing free fatty acids, and consequently reducing $\mathrm{pH}$ (Ambrozin et al., 2009). Therefore, $\mathrm{pH}$ variations are generally monitored as an indicator of microbial growth and biodiesel degradation (Passman, 2013; Soriano et al., 2015). Bento and Gaylarde (2001) reported reductions of up to 4 points in the $\mathrm{pH}$ of aqueous phase in response to biodiesel degradation. Cazarolli et al. (2012), and Bücker et al. (2014), however, found no reduction in the $\mathrm{pH}$ of aqueous phase when studying the same biocide. Such results may be related to the buffering effect of phosphates on mineral medium which could have masked the production of acid metabolites (Cazarolli et al., 2012). It may also be related to the characteristics of the biocide used (MBO) which has a high alkalinity reserve and could neutralize the organic acids formed (Siegert, 2009).

The estimation of microbial growth at the lab-scale showed that the biomass formed in the oil/water interface in the flasks containing the fuel treated with MA-MBO50 was on average $45.4 \pm 9.5 \%$ less than in the controls (untreated fuel) (Fig. 1). In the low-contamination microcosms (i.e., $10^{3} \mathrm{CFU} \mathrm{mL} \mathrm{m}^{-1}$ ), the biomass stood at $445.8 \pm 27 \mathrm{mgL}^{-1}$ in the control treatment (no biocide), $262.5 \pm 12.5 \mathrm{mgL}^{-1}$ in the $400 \mathrm{ppm}$ treatment, and $287.5 \pm 13 \mathrm{mgL}^{-1}$ in the $1000 \mathrm{ppm}$ treatment (Fig. 2). 


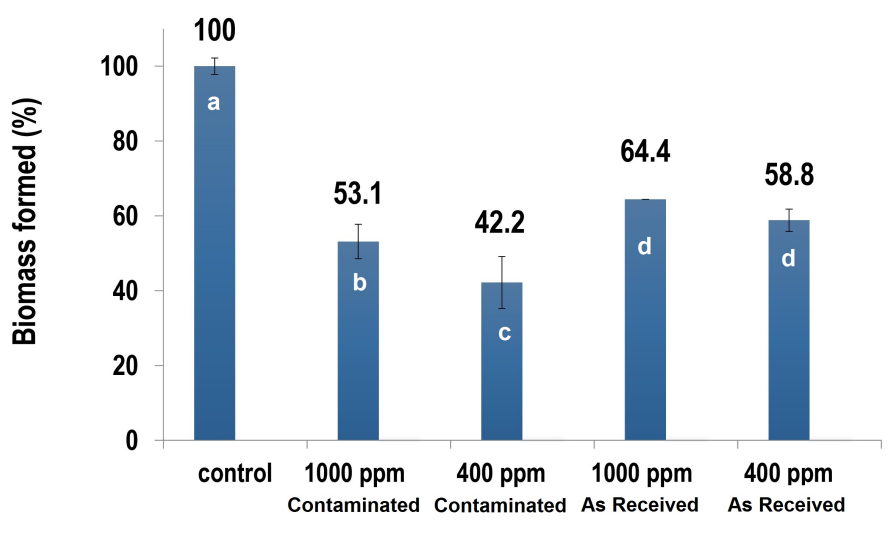

Treatment

Fig.1. Biomass percentage formed at the oil/water interface of the B10 blend treated with 400 $\mathrm{ppm}$ and $1000 \mathrm{ppm}$ of MA-MBO50in the low microbial contamination condition $\left(10^{3} \mathrm{CFU} \mathrm{mL}\right.$ $\left.{ }^{1}\right)$, and high microbial contamination condition $\left(10^{7} \mathrm{CFU} \mathrm{mL}{ }^{-1}\right)$, compared with the untreated controls after $35 \mathrm{~d}$ (at lab-scale). Same letters indicate no significant differences.

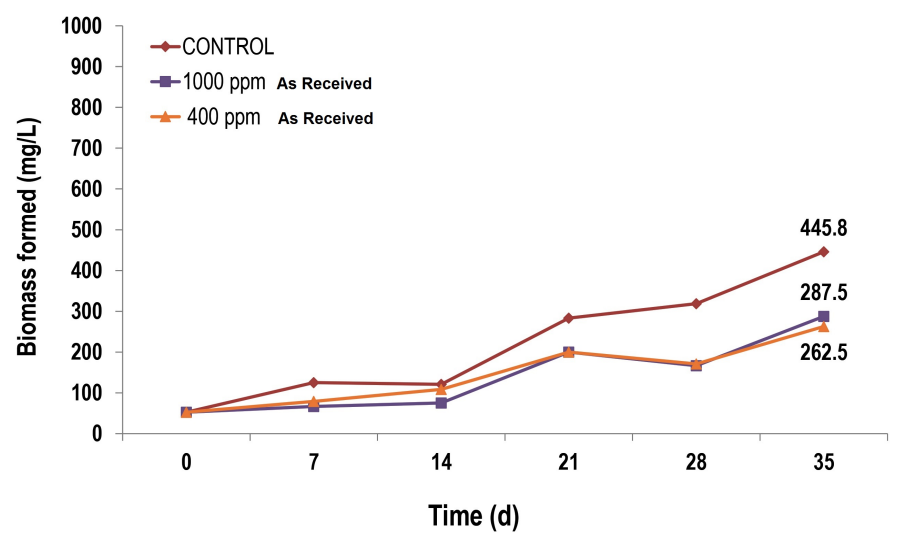

Fig.2. Biomass formed (mg/L) after $35 \mathrm{~d}$ in the B10 treated with $400 \mathrm{ppm}$ and 1000 ppm MAMBO50in the low microbial contamination condition $\left(10^{3} \mathrm{CFU} \mathrm{L}^{-1}\right)$ (condition as received). Each point on the graph represents the average of three replicates.

In better words, in the low-contamination microcosms, the biomass formed in the $400 \mathrm{ppm}$ and $1000 \mathrm{ppm}$ treatments was decreased by $41.2 \%$, and $35.6 \%$, respectively, compared with the control. This represents an average reduction of $38 \pm 4.0 \%$. There was no significant difference between the treatments 400 ppm and $1000 \mathrm{ppm}$ additive $(\mathrm{p} \geq 0.05)$ in the low-contamination treatment. In the high-contamination microcosms $\left(10^{7} \mathrm{CFU} \mathrm{mL} \mathrm{mL}^{-1}\right)$, the mean biomass was $800.0 \pm 57 \mathrm{mgL}^{-1}$ in the control, $300.0 \pm 37 \mathrm{mgL}^{-1}$ in the $400 \mathrm{ppm}$ treatment, and $425.0 \pm 39 \mathrm{mgL}^{-1}$ in the $1000 \mathrm{ppm}$ treatment (Fig. 3). The decreases observed in the formed biomass in the $400 \mathrm{ppm}$ and $1000 \mathrm{ppm}$ MA-MBO50 treatments were $57.8 \%$ and $46.9 \%$, respectively, when compared with the control. This represents an average reduction of $52.34 \pm 8 \%$. There was a significant difference $(p \leq 0.05)$ in the decreases observed in the biomass formed between the microcosms treated with 400 and 1000 ppm MA-MBO50.

Figures 2 and 3 show the effectiveness of the biocide over time in more detail. In the high-contamination treatment, it can be seen that after $14 \mathrm{~d}$, the microorganisms slowly resumed their growth, maintaining this trend until the $35 \mathrm{~d}$. In the low-contamination treatment, the biocide was effective for $28 \mathrm{~d}$; but after this time, the microorganisms resumed their growth. This result shows that the biocide was deactivated over time depending on the strength and the degree of microbial contamination, suggesting that a new administration of biocide would be necessary at certain intervals.

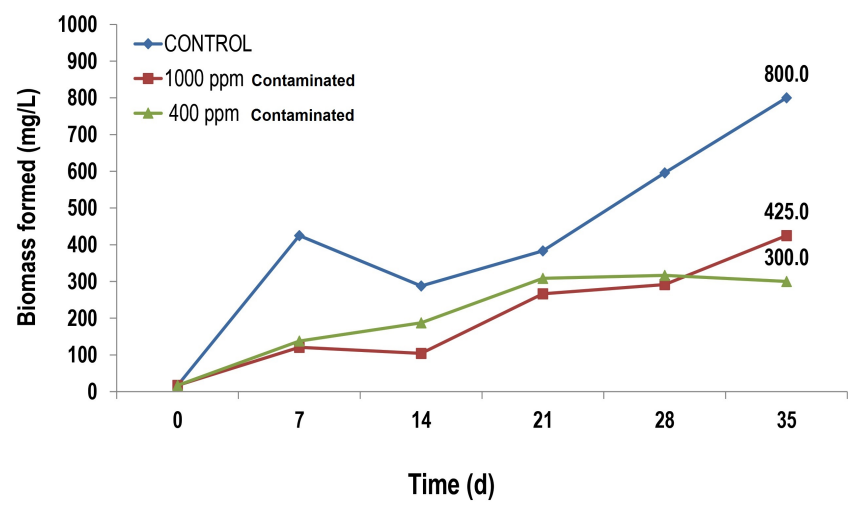

Fig.3. Biomass formed (mg/L) after $35 \mathrm{~d}$ in the B10 treated with $400 \mathrm{ppm}$ and $1000 \mathrm{ppm}$ $\mathrm{MA}-\mathrm{MBO} 50$ in the high microbial contamination condition $\left(10^{7} \mathrm{CFU} \mathrm{mL} \mathrm{mL}^{-1}\right)$. Each point on the graph represents the average of three replicates.

\subsubsection{Biomass production}

After $35 \mathrm{~d}$ of storage, the biomass formed in the microcosms appeared as a thin biofilm in the interface region or as a flocculated material dispersed in the aqueous phase. In the high-contamination treatment, the aqueous phase became very cloudy of milky appearance (Fig. 4). In both low and high contamination treatments, the $400 \mathrm{ppm}$ concentration was generally more effective in controlling microbial growth than the $1000 \mathrm{ppm}$ concentration. This finding was supported by those of Bücker et al. (2014), who also found no differences between the different concentrations investigated under similar conditions to those of the present study. Therefore, the $400 \mathrm{ppm}$ MA-MBO50 concentration was considered adequate to preventively protect the system (lab-scale). As a general rule, the amount of biocide applied should always be the lowest possible in order to minimize the cost and reduce the environmental impacts.

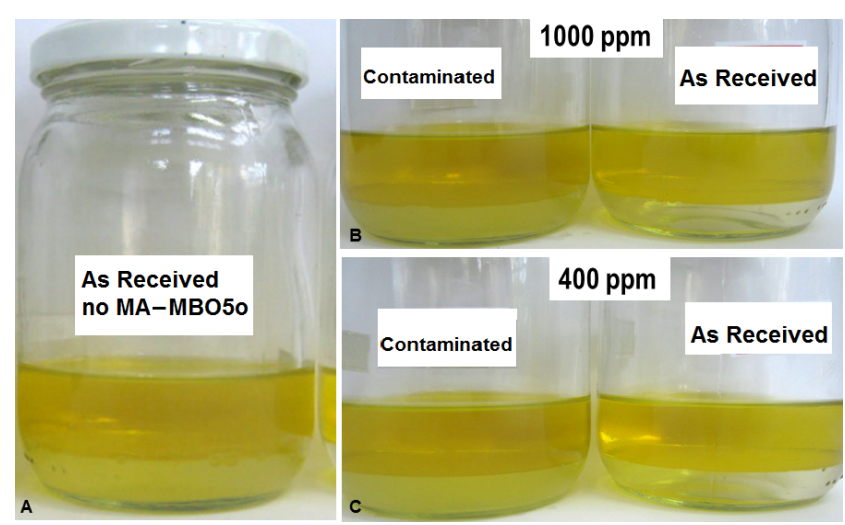

Fig.4. The appearance of the biomass formed at the oil/water interface in the flasks after 35 d (A: fuel not treated with MA-MBO50; B: fuel treated with 1000 ppm MA-MBO50; and C: fuel treated with 400 ppm MA-MBO50).

Although unusual, the increase of biomass when using a higher concentration of the product (1000 ppm) has also been reported by Bücker et al. (2014), using MBO, and by Raikos et al. (2012), using isothiazolones. In the study by Bücker et al. (2014), the concentration of 500 ppm MA- 
MBO50 was not effective as a preventive dosage and the biomass was 5.5 times higher than what formed without biocide. According to Raikos et al. (2012), the biomass increase may be related to several factors still poorly understood, such as the acquisition of tolerance by the microorganisms, biocide hydrolysis due to the higher volume of water, or a reduction of biocide available in the aqueous phase. Concerning the product used in this study, the availability of the other nutrients present in the formulation could have also contributed to the increase in biomass. According to Cloete et al. (1989), Costerton (1989), and Trafny et al. (2015), the resumption of microbial growth often occurs by detachment of viable cells of the biofilm or microbial succession. Microbial succession occurs when susceptible groups of microorganisms are killed and biocide concentrations decrease. Other groups, less susceptible to this biocide and maybe less representative in the initial community, may start a new growth stage.

\subsection{Field-scale \\ 3.2.1. Estimation of microbial development: $C F U$}

The microbial growth in the aqueous phase was monitored by plate counting of viable cells. The results can be seen in Figures 5 and 6 . In the low-

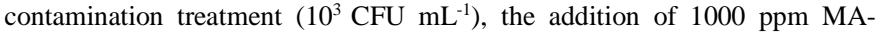
MBO50 reduced the microbial population to undetectable levels $\left(<10^{2} \mathrm{CFU}\right.$ $\left.\mathrm{mL}^{-1}\right)$ after $7 \mathrm{~d}$ (Fig. 5). In the high-contamination treatment $\left(10^{7} \mathrm{CFU} \mathrm{mL} \mathrm{mL}^{-1}\right)$, no differences were observed in microbial growth between tanks with MAMBO50 and the controls (Fig. 6).

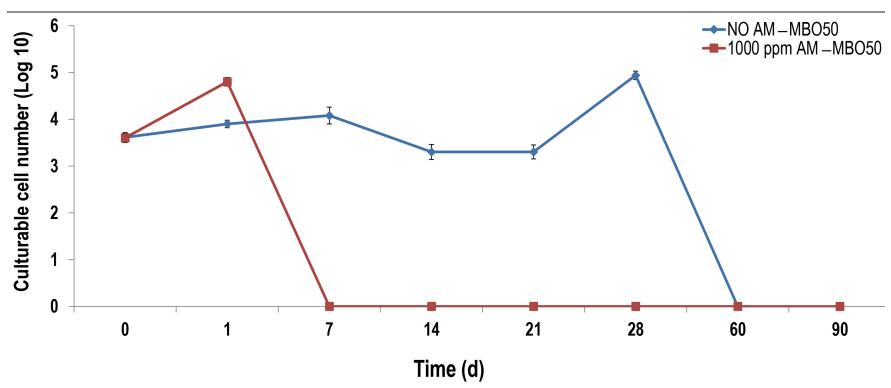

Fig.5. Microbial growth in the aqueous phase and B10 mixture under simulated storage conditions, with and without additive in the low contamination condition $\left(10^{7} \mathrm{CFU} \mathrm{mL}^{-1}\right)$.

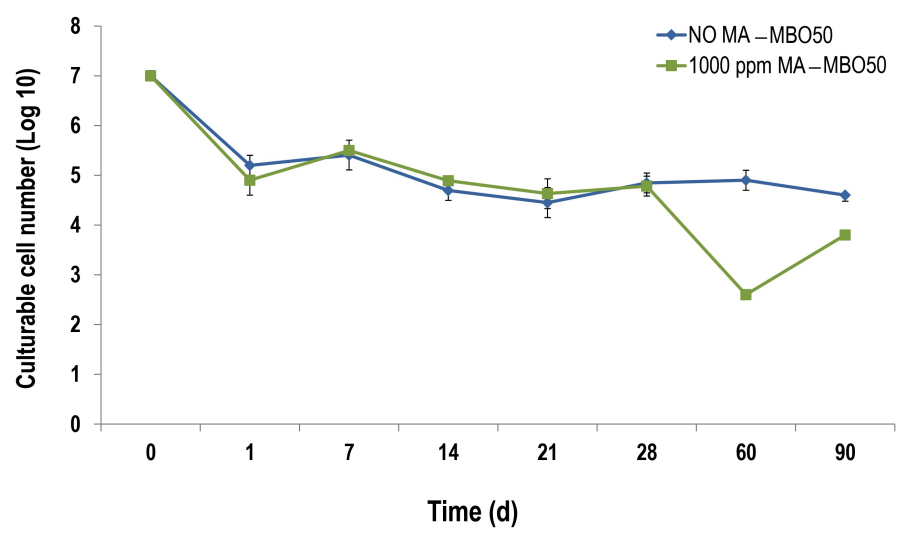

Fig.6. Microbial growth in the aqueous phase and B10 blend mixture under simulated storage conditions, with and without additive in the high contamination condition $\left(10^{7} \mathrm{CFU} \mathrm{mL} \mathrm{mL}^{-1}\right)$.

\subsubsection{Biomass formation}

The microbial growth, assessed through the biomass (dry weight) formed in the oil/water interface at the end of the experiment, in tanks treated with MAMBO50 was on average 35\% lower than in the controls (Fig. 7). In the lowcontamination treatment $\left(10^{3} \mathrm{CFU} \mathrm{mL} \mathrm{m}^{-1}\right)$, the biomass was on average $33 \%$ lower in tanks containing 1000 ppm MA-MBO50 than in the controls. In the high-contamination $\left(10^{7} \mathrm{CFU} \mathrm{mL}^{-1}\right)$, the average biomass reduction was $37 \%$ when the fuel was treated with $1000 \mathrm{ppm}$ MA-MBO50. There was a significant difference $(\mathrm{p} \leq 0.05)$ between the average biomass formed in tanks containing the fuel treated with $1000 \mathrm{ppm}$ MA-MBO50, compared with those which contained untreated fuel. Under this condition, MAMBO50 retained its effectiveness for up to $60 \mathrm{~d}$, even in the highcontamination treatment.

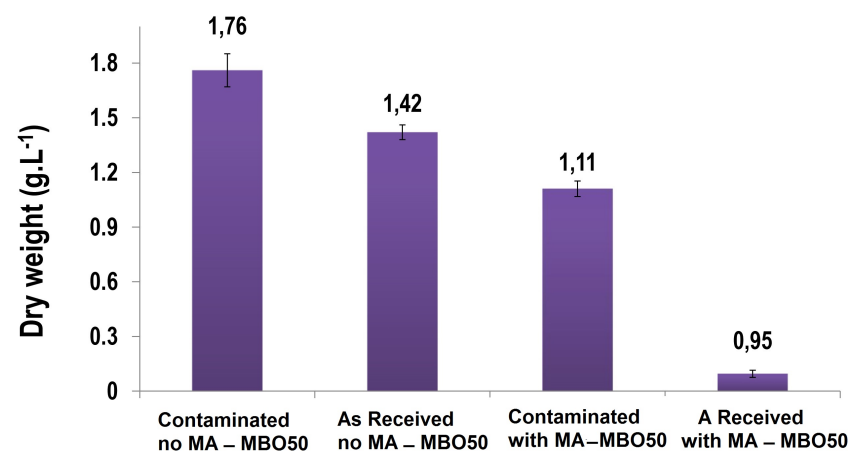

Treatment

Fig.7. Average dry weight values of the formed biomass $\left(\mathrm{gL}^{-1}\right)$ in the tanks containing B10 after $90 \mathrm{~d}$ of simulated storage (field/real-world condition) with and without additive in the

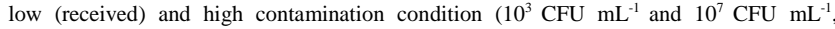
respectively).

\subsubsection{Biomass feature}

In the field experiment in the high-contamination treatment, the standard plate counts and the biomass estimate appeared to lead to antagonistic results. Standard plate counts suggested that the addition of $1000 \mathrm{ppm}$ MAMBO50 had no effect on the microbial population (Fig. 6). However, after $90 \mathrm{~d}$, the biomass in the treated tanks was 33\% lower than in the controls, suggesting that MA-MBO50 had a biostatic effect in the highcontamination treatment. To provide a better explanation for this result, a visual analysis of the biomass formed after $90 \mathrm{~d}$ was performed. This analysis revealed marked differences between the distribution of microbial cells in tanks treated with the additive and the controls. In the controls, the biomass formed in the oil/water interface strongly adhered to the bottom, forming a dense solid film (biofilm). This biofilm was mainly constituted by filamentous fungi, approximately $0.2 \mathrm{~cm}$ thick, with dark coloration in the center and whitish edges (Figs. 8A and B). In the treated tanks, however, the biomass was basically formed by planktonic cells and had a liquid, sparse, and yellowish appearance, with no adhesion points (Figs. 8C and D). Microorganisms growing in a biofilm are immersed within a polysaccharide matrix and the increase in cell number can only be perceived as an increase in biofilm thickness, thus it is difficult to estimate the actual development by standard plate counts. In the tanks where the formation of a biofilm was not detected (1000 ppm MA-MBO50), the cells were distributed evenly in the fuel, allowing a better estimation of microbial growth with standard plate counts. Therefore, despite the direct plate counts results being very similar, it was likely that the total number of microorganisms in the controls was much higher than in the treated tanks. Passman, (2013) warned about difficulties in accurately determining the microbial counts of stored fuel due to a differential distribution of microorganisms in the tanks as well. Hettige and Sheridan (1989) also noticed differences between the laboratory and field experiments in terms of the cell counts obtained using the standard method, suggesting that these differences were related to cell clumping, sedimentation, interactions among the microbial populations, as well as seasonal and biocide effects. In the present study, the use of the dry weight technique allowed the 


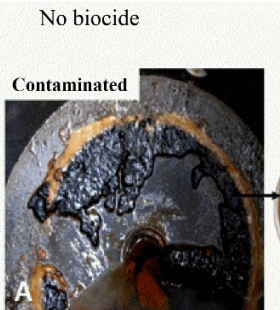

Formed biomass
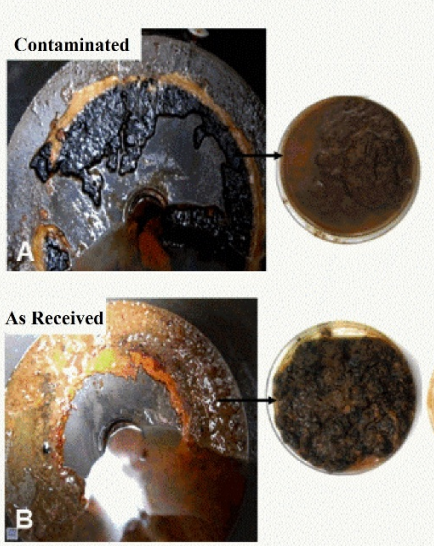

With biocide
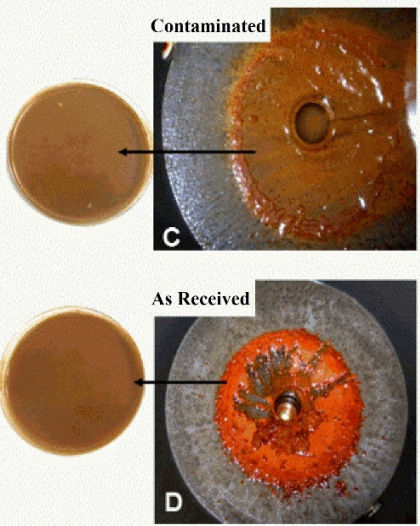

Fig. 8. Appearance of the biomass formed and adhered to the bottom of the tanks after $90 \mathrm{~d}$ (A: B10 contaminated without additive; B: B10 received (low contamination condition) without additive; and C: B10 contaminated with additives; D: B10 received with additive.

visualization of the additive's effect on the microbial community distribution. Biocide effect, accessed through the biomass formed after $90 \mathrm{~d}$, indicated a biostatic action on this microbial population in the high-contamination treatment with 1000 ppm MA-MBO50, as compared with the controls.

In the experiments carried out herein, it was observed that the development of the biomass in the untreated fuel was visually distinct compared with the treated sample. Visual inspection showed that the assessed biocide prevented, or at least, greatly reduced biofilm formation in the tanks where it was added. This can be evaluated as an important benefit associated with the use of the tested biocide as a preventive strategy since biofilm formation is closely related to the biocorrosion processes (Passman, 2013; Bücker et al., 2014). Bücker et al. (2014) investigated the microbial diversity in a similar laboratory experiment, and found that the addition of $400 \mathrm{ppm}$ MA-MBO50 to B10 blend had a significant impact on the microbial diversity. The authors reported $99.8 \%$ decrease in the diversity of the microorganisms in the flasks with native microbiota (as received) after $28 \mathrm{~d}$. Despite that, the taxonomic diversity of the native community was still three times higher than the inoculated community.

Studies assessing biocides and their use in fuels are generally performed at lab-scale by using minimal mineral media to simulate the aqueous phase with the fuel as the oil phase. Only a few studies have been conducted on a larger scale (Hettige and Sheridan, 1989; Passman, 2013), and even less have used storage periods longer than $30 \mathrm{~d}$ (Andrykovitch et al., 1987; Hettige and Sheridan, 1989; Zimmer et al., 2013; Bücker et al., 2014). The evaluation of biocides in laboratory tests is very important as it allows a preliminary assessment of their effectiveness and of the interactions between the biocide and the fuel. However, practical limitations of laboratory tests are not enough to ensure its efficiency in real-use conditions (Hettige and Sheridan, 1989; Schwingel and Eachus, 2009). Table 1 shows a comparison between the results of the laboratory and field experiments.

The effectiveness of a biocide in oil/water systems depends on many factors such as action spectrum; indicated concentration for use; partition coefficient of a product; level of microbial contamination; chemical composition of the medium; and the composition and distribution of microbial populations (Raikos, 2012; Passman, 2013; Zimmer et al., 2013). Most tests only evaluate the effectiveness of biocides in planktonic populations (Geva, 1992 and 2007; Siegert, 2009; Browne, 2011; Passman, 2013). In order to quantify the population, those tests use techniques that

Table 1.

Comparison of the effect of the multifunctional additive, i.e., AM-MBO50 containing a biocide as 50\% of its formulation under the lab-scale and field scale (real-world condition) conditions using B10 and at low (received) and high (contaminated) contamination levels.

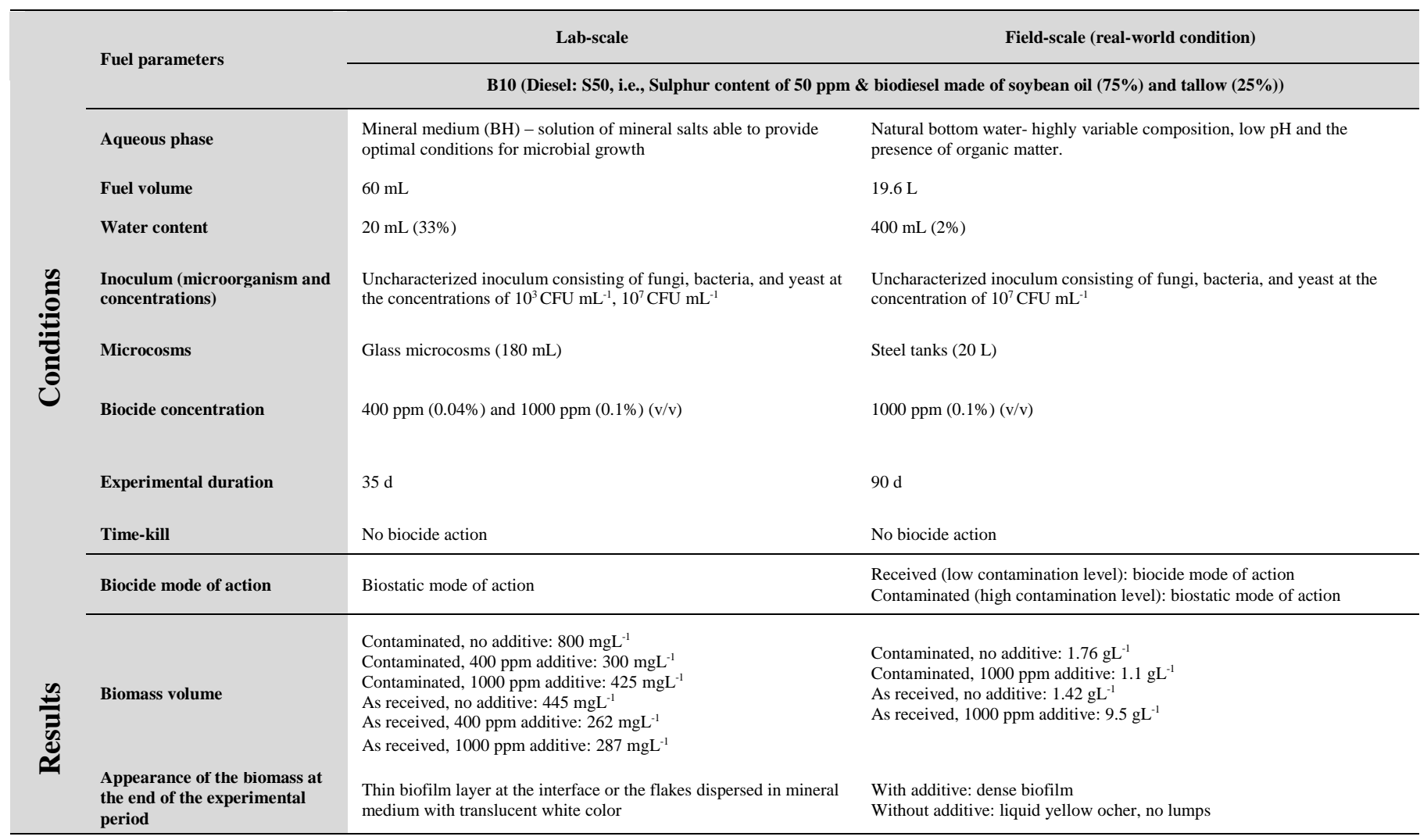

Please cite this article as: Zimmer A.R., Oliboni A., Viscardi S.L.C., Teixeira R.M., Ferrão M.F., Bento F.M. Biodiesel blend (B10) treated with a multifunctional additive (biocide) under simulated stored conditions: a field and lab scale monitoring. Biofuel Research Journal 14 (2017) 627-636. DOI: 10.18331/BRJ2017.4.2.7 
disregard the presence of biofilms such as direct plate counts and indirect estimation by ATP bioluminescence (Geva, 2007; Dodos et al., 2011; Dodos and Zannikos, 2013). Thus, biostatic effects and the effectiveness of the biocide on biofilm formation are often ignored. In this study, it was possible to assess the biocide effect on native microbial populations (received condition) and added population (high-contamination), by investigating the biomass produced in the oil/water interface and the visual observations indicated that microbial growth was controlled in the tanks treated with 1000 ppm MA-MBO50.

There were many differences between the two experiments conducted in this work including the oil/water ratio, the aqueous phase type, and the microcosm used in the total volume of the experiment. These collectively lead to clearer conclusion about the effectiveness of the tested biocide. In the lab-scale experiment, a $400 \mathrm{ppm}$ concentration of the product was proven to be sufficient for controlling low-contamination situations. However, the field-scale study, in which conditions were closer to real-world situations (such as the metallic surface of the tank), the necessity of a higher dosage of the product, i.e., 1000 ppm was found effective. Possible explanations for the difference in product's dosage in the two scales may be related to the complex chemical composition of natural bottom water containing organic matters as well as its lower $\mathrm{pH}$. Chemical interactions between water and biocide could make it more rapidly consumed, reducing its effect on the microbial population. The slow development of microorganisms may be caused by the poor nutritional support provided by the aqueous phase, leading to an increased tolerance of these microorganisms to numerous antibiotics (Brauner et al., 2016).

\subsection{Chemical parameters analysis}

Environmental variables such as $\mathrm{pH}$, temperature, and humidity also contribute to the degradation processes of stored fuels. These processes are mainly evidenced by changes in acidity index, oxidation stability, water content, specific gravity (density), and viscosity; and for this reason, these parameters were monitored throughout the study.

The $\mathrm{pH}$ of the natural bottom water was recorded at each sampling time over the $90 \mathrm{~d}$ experiment, and it remained in the range of 4 (acidic condition). The environmental temperature ranged between $11^{\circ} \mathrm{C}$ and $26^{\circ} \mathrm{C}$ and the internal temperature (inside the tank) ranged between $9^{\circ} \mathrm{C}$ and $20^{\circ} \mathrm{C}$, During the same period, the relative humidity varied between $54 \%$ and $100 \%$. During sampling, water condensation on the tanks walls or lids was not observed, neither was turbidity in the fuel.

The chemical stability of the stored fuel throughout the experimental period was evaluated through the alteration of its physic chemical properties. The greatest differences between the controls and the $1000 \mathrm{ppm}$ MA-MBO50 treatment were seen in terms of the oxidation stability and water content (Fig. 9). In the1000 ppm MA-MBO50 treatment (tanks 5-8), both oxidation stability and water content remained unchanged after $90 \mathrm{~d}$ of storage (Fig. 9), whereas in the controls, after $90 \mathrm{~d}$ of storage at maximum $20^{\circ} \mathrm{C}$, there was an increase of up to three times in water content of the B10 blend (Fig. 9). This increase can in part be explained by the microbial growth which occurred inside the controls, as it is known that microorganisms may release water as a result of their metabolism (Kavanagh et al., 2011).

Water in fuel may be present in three different forms: free, dissolved, or emulsified, depending primarily on the temperature. Lower temperatures promote the appearance of a free-water phase which is deposited in the tank bottom, favoring microbial growth in the oil/water interface. Higher temperatures may increase fuel turbidity through water absorption (dissolved water) (Passman, 2013).

As biodiesel is very hygroscopic, diesel/biodiesel blends tend to contain more water than diesel oil, and the ability to absorb water depends on the biodiesel content in the blend (Fregolente et al., 2012; Strömberg et al., 2013). Fregolente et al. (2012), studying soybean biodiesel and diesel S50 (LSD) blends, observed that at $20^{\circ} \mathrm{C}$ and relative humidity of $80 \%$, blends with less than $20 \%$ biodiesel content absorbed up to $90 \%$ less water than blends with higher biodiesel percentages. Strömberg et al. (2013) reviewed the water content in blends with $7 \%$ canola biodiesel and ultra-low sulfur diesel $(10 \mathrm{ppm})$ stored during $14 \mathrm{~d}$. The authors also did not observe any variations in the water content of the studied blends, while in pure biodiesel a steady increase in water content was observed. In an experiment conducted by Zimmer et al. (2012), different quality parameters for diesel/biodiesel blends (i.e., B5, and B20) were evaluated for $120 \mathrm{~d}$ storage period, with and without antioxidant addition, and did not observe any increases in water content. However, all the experiments were performed with fuel volumes between $200 \mathrm{~mL}$ and $1 \mathrm{~L}$, and therefore, possible changes
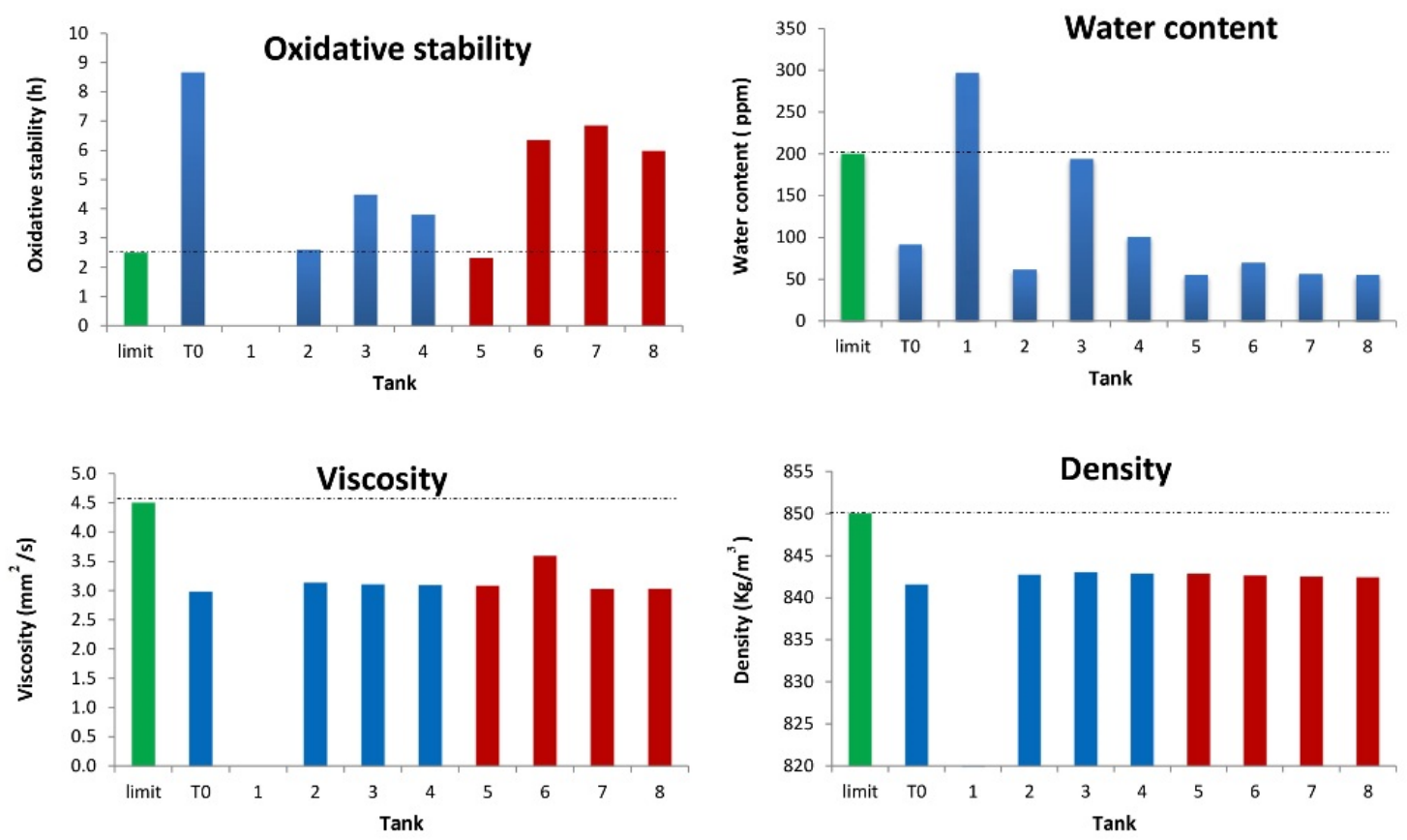

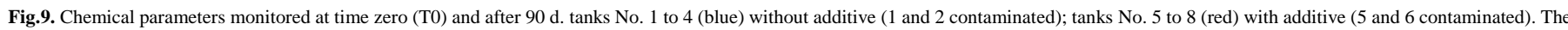
dotted line (...) represents the maximum limit of the analyzed parameter according to the ANP. 
in water content may have been masked by the difficulty of working with low fuel volumes. The present study was conducted with a larger volume $(20 \mathrm{~L})$, which may have allowed a clearer evaluation of changes in water content. Another possible explanation for changes in the water content may be that other chemical components present in the additive formula, such as dispersants, prevented water absorption.

The oxidative stability parameter indicates the fuel's capacity to resist to physical and chemical changes upon interactions with the environment (Berrios et al., 2012), which can in turn also induce negative changes in viscosity and $\mathrm{pH}$, accentuating the fuel deterioration (Cavalcanti, 2009). In general, the application of additives may extend the oxidation stability of blends for 8 to 10 weeks, but this can vary depending on biodiesel content (Karavalakis et al., 2010). Diesel/biodiesel blends with a lower percentage of biodiesel (up to 20\%) generally undergo fewer changes (Mazumdar et al., 2013). The current Brazilian biodiesel regulation (Resolution ANP 50/2013; Technical Report ANP 04/2013) establishes a value of $2.5 \mathrm{mg} / 100 \mathrm{~mL}$ for oxidative stability of biodiesel blend with diesel S10 (ULSD). However, when this study was conducted, the Brazilian regulation established an oxidative stability value for pure biodiesel only (6 h induction period - ASTM D14112 or EN 15751). For this reason, the standard ASTM D14112 was adopted to determine oxidation stability.

In this study, a reduction of $50 \%$ to $75 \%$ (from $9 \mathrm{~h}$ at time zero to values between 3 and $5 \mathrm{~h}$ after $90 \mathrm{~d}$ ) in oxidative stability after $90 \mathrm{~d}$ of simulated storage was observed in the controls (tanks 1-4), whereas in the 1000 ppm MAMBO50 treatment, it remained within the specification values. Berrios et al. (2012) evaluated a commercial blend of 5\% biodiesel under storage conditions for180 d and found no significant changes in the fuel properties. Similarly, McCormick and Westbrook (2009) did not observe any changes in the oxidation stability of blends with $5 \%$ and $20 \%$ biodiesel stored for 12 weeks. The authors concluded that the stability of blends was related to the stability of the pure biodiesel used in the blends. When pure biodiesel presents an induction period longer than $3 \mathrm{~h}$, the oxidation stability of the blend with $5 \%$ biodiesel may remain unchanged for up to one year (McCormick and Westbrook, 2009). For blends of $20 \%$ biodiesel, this period decreases to 4 months (McCormick and Westbrook, 2009). Zimmer et al. (2010), studying pure diesel (B0), pure biodiesel (B100), as well as B5 and B20 blends with and without antioxidant stored for $120 \mathrm{~d}$, observed that the oxidative stability of the pure biodiesel was out of specifications after $30 \mathrm{~d}$. On the contrary, the blends had an average induction period of $8 \mathrm{~h}$ after $120 \mathrm{~d}$. None of the studies mentioned above linked the contribution of microbial contamination or water content with the changes in oxidation stability. Schleicher et al. (2009), however, related the reduction of oxidation stability to the presence of microbial contamination. The authors reviewed the oxidation stability of B100, B20, and B5 which were stored contaminated with no addition of water. Despite of the low contamination observed $\left(\max 1.7 \times 10^{3} \mathrm{CFU} \mathrm{mL}^{-1}\right.$ ), contaminated samples underwent greater reductions in oxidation stability than those not contaminated (Schleicher et al., 2009).

Microorganisms growing in fuel can accelerate and intensify chemical degradation by two different processes. First, by the release of organic acids and other compounds resulted from microbial metabolism in the environment, and second, by the degradation of additives that are meant to preserve fuel quality (Bento and Gaylarde, 2001; Rodríguez-Rodríguez et al., 2009; Dodos et al., 2011; Passman, 2013; Soriano et al., 2015). However, the presence of water is considered as one of the most negative factors jeopardizing oxidation stability (Ambrozin et al., 2009). In the present study, the marked reduction in oxidation stability observed in the controls can be explained mainly by the sum of three factors: the presence of microbial contamination, the large amount of water dissolved in the fuel, and to a lesser extent, the lower amount of additive in the fuel. It is worth mentioning that the used fuel herein was a combination of a biocide and additives which increased the total amount of additives in the tanks with fuel treated with MA-MBO50.

A visual analysis of the bottom of the drained tanks revealed the characteristics of the products formed during storage and also the damages to the tanks structure after the experiment. Tanks containing the control treatment had a mucilaginous sludge and an adhered biofilm (Fig. 10), suggesting that the biocide-tolerant microbial populations may have produced a protective polysaccharide matrix. The damage caused to the tanks that received fuel with 1000 ppm MA-MBO50 was visually less than what was observed in the controls. This difference was probably related to the release of acid metabolites by microbial metabolism, and to the presence of biofilm attached to the tank surface that may favor the occurrence of microbiologicallyinfluenced corrosion (MIC). The multifunctional additive evaluated under the conditions of this study acted preventively in terms of the microbial control.

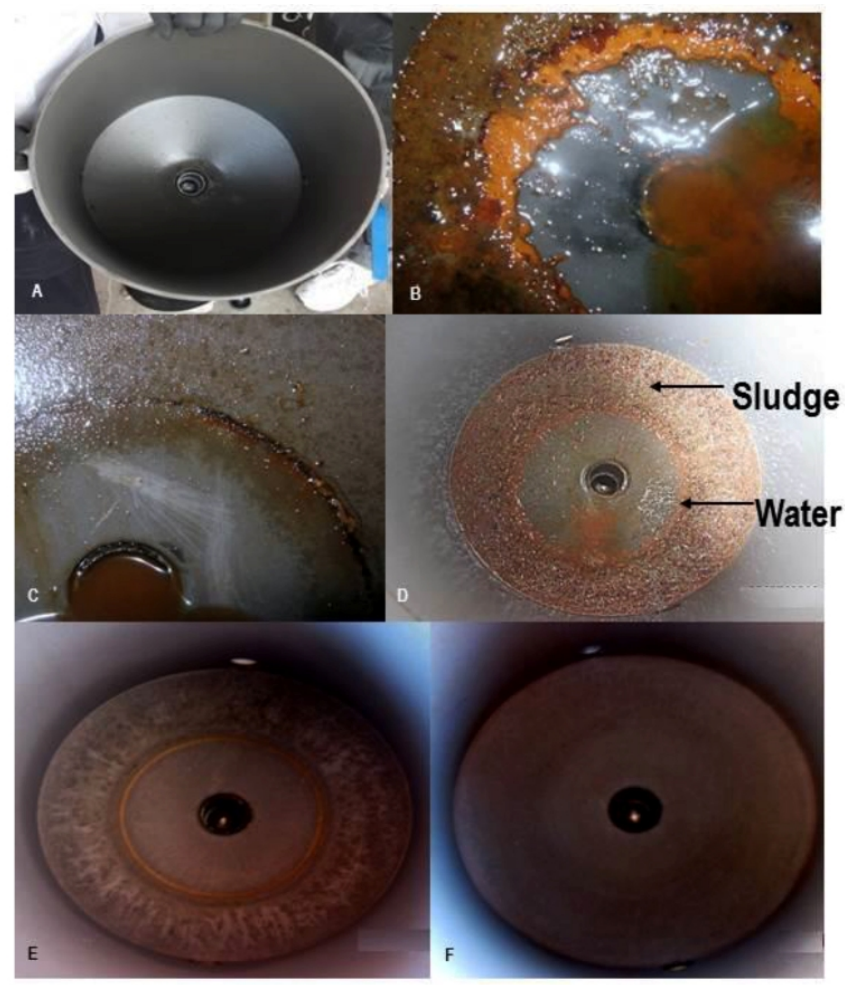

Fig. 10. Appearance of the tanks`surface and the presence of sludge (biological/chemical) A: The tank at time zero before adding the fuel; B: mucilaginous sludge formed at the end of $90 \mathrm{~d}$ in the tanks containing the untreated fuel blend; C and D: fuel tanks which contained the untreated fuel after $90 \mathrm{~d}$ with a high microbial contamination (the arrow shows the area where biofilm settlement took place); E: appearance of the tank`s surface $90 \mathrm{~d}$ after the addition of the untreated fuel; and F: appearance of the tank`s surface $90 \mathrm{~d}$ after the addition of the treated fuel.

The MBO active ingredient is known to be a broad-spectrum biocide quite effective in controlling anaerobic microorganisms such as sulfatereducing bacteria (BRS), which is usually responsible for corrosion influenced by microorganisms (Siegert, 2009; Passman, 2013). MBO also has the ability to neutralize acids formed by microbial metabolism as well as the formation of degradation products (Siegert, 2009; Passman, 2013). This biocide has been found effective at a concentration of $200 \mathrm{ppm}$ in preventing bacteria and fungi from growing separately in oil and mineral medium (Siegert, 2009). However, Zimmer et al. (2013) found that this biocide, used in the MA-MBO50 formulation at $400 \mathrm{ppm}$ and $1000 \mathrm{ppm}$, showed only biostatic action against microbial contamination in a B10 blend. It is worth emphasizing that the concentration of the active ingredient (MBO biocide) in this product was $50 \%$, which roughly corresponds to a concentration of $200 \mathrm{ppm}$ and $500 \mathrm{ppm}$ of the active ingredient in the system, respectively. In addition, the same study showed that MA-MBO50 was less effective in controlling contamination of diesel/biodiesel blends (B7 and B10) compared with pure diesel or biodiesel (Zimmer et al., 2013). The use of biocides in combination with other chemicals to protect fuel was studied by Geva (1992). The author suggested that the biocide effectiveness may be affected by the interaction with other components of the product and/or by changes in the biocidal partition coefficient. The biocidal partition coefficient would result in a reduced availability of the active ingredient in the aqueous phase (Raikos et al., 2012).

The presence of chemical or biological sludge is another fact that can contribute to the reduction of biocide effectiveness (Andrykovitch et al. 1987; Zimmer et al., 2013). The type of fuel could also contribute to the effectiveness reduction of a given biocide (Browne, 2011). According to 
Pereira et al. (2000), biocide adsorption to clay or organic matter influences its availability to microorganisms, causing them to partially or totally lose their toxic activity. On the other hand, it is generally assumed that particle-attached bacteria are less sensitive to biocides than the same bacteria in a planktonic state (Nichols, 1989). The product evaluated herein contained other chemical compounds as well whose function was to ensure a broader treatment of fuel, such as corrosion inhibitors, antioxidants, dispersants, detergents, etc. These compounds could have probably contributed to the lesser changes observed in the 1000 ppm MA-MBO50 treatment over $90 \mathrm{~d}$, as compared with the controls.

In the tanks containing the fuel treated with additives, for example, the biomass observed was not as thick as the one formed in the oil/water interface of the tanks containing the untreated fuel. The formation of biological films is a serious problem associated with the problems of corrosion and premature saturation of filters, pipes, and injection systems. Biological films are considered as the biggest problem in fuel storage systems with a high product turnover rate (Passman, 2013). Dispersants and emulsifiers are part of the product formulation used in this study (according to manufacturer's information) and may have been responsible for the difficulty to access the biofilm, especially in the tanks with high contamination. Another factor that needs to be considered is the presence of biocide in the additive formulation, which may have changed the composition of the microbial population (eliminating several species including those involved in biofilm formation), or prevented their development.

\section{Conclusions}

This study evaluated the effectiveness of the multifunctional additive MAMBO50 as biocide in the treatment of diesel/biodiesel blends at two different scales, laboratory and field. The lab-scale study showed that, at a $400 \mathrm{ppm}$ concentration, this product was able to inhibit biomass formation in the range of $40 \%$ to $60 \%$ during simulated fuel storage in the microcosms. Under the same conditions, the $1000 \mathrm{ppm}$ concentration showed a smaller decrease in biomass development, suggesting that overdosing may have an inverse effect on the desired since it can provide a higher amount of nutrients and promote microbial growth.

In the field-scale study, the multifunctional additive at a $1000 \mathrm{ppm}$ concentration showed a biocide action after $7 \mathrm{~d}$ in the tanks with low microbial contamination and a biostatic action in the tanks receiving microbial inoculum (high contamination). In the tanks containing the treated fuel, the biomass and biofilm formation in the oil/water interface was significantly reduced. Moreover, the fuel characteristics guaranteeing chemical stability remained within the specification limits required by ANP after $90 \mathrm{~d}$.

This study showed that due to the changes in the internal conditions of the tanks including the presence of organic matter, degradation products, and water quantity, the dosage of the product used may require adjustments. It also reinforced the fact that the dosages often defined at lab-scale may require adjustments under practical (real world) conditions.

\section{Acknowledgements}

The authors wish to express their appreciation to Ipiranga Petroleum Products for providing fuels and technical support. The funding was provided by MCT/CGTS and FINEP, agreement number 01.08.0442.00 (Consolidation ARMAZBIOD Network project), CNPq, and Capes.

\section{References}

[1] Ambrozin, A.R.P., Kuri, S.E., Monteiro, M.R., 2009. Corrosão metálica associada ao uso de combustíveis minerais e biocombustíveis. Química ova.32(7), 1910-1916.

[2] Andrykovitch, G., Niehof, R.A., 1987. Fuel-soluble biocides for control of Cladosporium resinae in hydrocarbons fuel. J. Ind. Microbiol. Biotechnol. 2(1), 35-40.

[3] Bento, F.M., Gaylarde, C.C., 2001. Biodeterioration of stored diesel oil: studies in Brazil. Int. Biodeterior. Biodegrad. 47(2), 107-112.

[4] Berrios, M., Martín, M.A., Chica, A.F., Martín, A., 2012. Storage effect in the quality of different methyl esters and blends with diesel. Fuel. 91(1), 119-125.
[5] Brauner, A., Fridman, O., Gefen, O., Balaban, N.Q., 2016. Distinguishing between resistance, tolerance and persistence to antibiotic treatment. Nat. Rev. Microbiol. 14(5), 320-330.

[6] Browne, A.B., 2011. Sustainable and effective preservation strategies for ultra low sulphur diesel biodiesel and unleaded gasoline, in: IASH, The $11^{\text {th }}$ International Conference on Stability. Handling and use of liquid fuels, Sarasota, Florida, USA. 16-20.

[7] Bücker, F., Barbosa, C.S., Quadros, P.D., Bueno, M.K., Fiori, P., te Huang, C., Frazzon, A.P.G., Ferrão, M.F., de Oliveira Camargo, F.A., Bento, F.M., 2014. Fuel biodegradation and molecular characterization of microbial biofilms in stored diesel/ biodiesel blend B10 and the effect of biocide. Int. Biodeterior. Biodegrad. 95, 346355 .

[8] Bushnell, L.D., Haas, H.F., 1941. The utilization of certain hydrocarbons by microorganisms. J. Bacteriol. 41(5), 653-673.

[9] Cavalcanti, E.H.S., 2009. Estabilidade do biodiesel e misturasabrangência, limitações dos métodos de avaliação e alternativas futuras. Biodieselbr. 3, 71-73.

[10] Cazarolli, J.C., Bücker, F., Manique, M.C., Krause, L.C., Maciel, G.P.D.S., Onorevoli, B., Caramão, E.B., Cavalcanti, E.H.D.S., Samios, D., Peralba, M.D.C.R., Bento, F.M., 2012. Suscetibilidade do biodiesel de sebobovino à biodegradaçãopor Pseudallescheria boydii. Revista Brasileira de Biociências. Porto Alegre. 10(3), 251257.

[11] Cazarolli, J.C., Guzatto, R., Samios, D., Peralba, M.D.C.R., de Siqueira Cavalcanti, E.H., Bento, F.M., 2014. Susceptibility of linseed, soybean, and olive biodiesel to growth of the deteriogenic fungus Pseudallescheria boydii. Int. Biodeterior. Biodegrad. 95, 364 372 .

[12] Cloete, T.E., Smith, F., Steyn, P.L., 1989. The use of planktonic bacterial populations in open and closed recirculating water cooling systems for the evaluation of biocides. Int. Biodeterioration. 25(1-3), $115-122$.

[13] Costerton, J.W., Lappin-Scott, H.M., 1989. Behaviour of bacteria in biofilms. ASM NEWS. 55, 650-654.

[14] de Azambuja, A.O., Bücker, F., de Quadros, P.D., Zhalnina, K., Dias, R., Vacaro, B.B., Correa, C., Ferrão, M.F., de Oliveira Camargo, F.A., Triplett, E., Bento, F.M., 2017. Microbial community composition in Brazilian stored diesel fuel of varying sulfur content, using high-throughput sequencing. Fuel. 189, 340-349.

[15] Dodos, G.S., Konstantakos, T., Longinos, S., Zannkos, F., 2011. Effects of microbiological contamination in the quality of biodiesel fuel. Global NEST J. 14(2), 175-182.

[16] Dodos, G.S., Zannikos, F., 2013. Microbiological growth study of biodiesel fuel. SAE Int. J. Fuels Lubr. 6(2), 419-429.

[17] Fregolente, P.B.L., Fregolente, L.V., Wolf Maciel, M.R., 2012. Water content in biodiesel, diesel, and biodiesel-diesel blends. J. Chem. Eng. 57(6), 1817-1821.

[18] Geva, J., Geissmann, E., Ittah, E., Nakdimon, I., Sapir, Y., Fass, R., 2007. ATP analyses as a tool to determine the need to clean the fuel tanks of diesel motivated vehicles before refouling with biocides and stability improving additives. in: IASH2007, $10^{\text {th }}$ International Conference on Stability. Handling and use of liquid fuels, Tucson, Arizona. 7-11.

[19] Geva, J., Propes, J., Papier, J., Busanni, M., Zehavi, E., Fass, R., 1992. Effects of stabilizing additives on the susceptibility of diesel fuels to microbial attack. in: Giles, H.N. (Ed.), Proceedings of the $4^{\text {th }}$ International Conference on Stability and Handling of Liquid Fuels. Orlando, Florida.

[20] Hettige, G.E., Sheridan, J.E., 1989. Interactions of fungi contaminating diesel fuel. Int. Biodeterior. 25(4), 299-309.

[21] Hill, E.C., Hill, G.C., 2000. Detection and remediation of microbial spoilage and corrosion in aviation kerosene-From refinery to Wing, in: IASH2000, The $7^{\text {th }}$ International Conference on Stability. Handling and use of liquid fuels, Graz, Austria.

[22] Hill, E.C., Hill, G.C., 2009. Strategies for resolving problems caused by microbial growth in terminals and retail sites handling biodiesels, in: IASH2009, The $11^{\text {th }}$ International Conference on Stability. Handling and use of liquid fuels, Prague, Czech Republic. 
[23] Karavalakis, G., Stournas, S., Karonis, D., 2010. Evaluation of the oxidation stability of diesel/biodiesel blends. Fuel, 89(9), 2483-2489.

[24] Kavanagh, K., 2011. Fungi: biology and applications, second edition, in: National University of Ireland Maynooth, (Ed.), Wiley-Blackwell, Chichester, pp. 366.

[25] Mazumdar, P., Borugadda, V.B., Goud, V.V., Sahoo, L., 2013. Effect of storage parameters on stability of Jatropha-derived biodiesel. Int. J. Energy Environ. Eng. 4(1), 13.

[26] McCormick, R.L., Westbrook, S.R., 2009. Storage stability of biodiesel and biodiesel blends. Energy Fuels. 24(1), 690-698.

[27] Nichols, W.W., 1989. Susceptibility of biofilms to toxic compounds. Structure and Function of Biofilms, Characklis, W.G., Wilderer, A. (Eds.), Wiley-Interscience, pp. 321-331.

[28] Passman, F.J., 2013. Microbial contamination and its control in fuels and fuel systems since 1980-a review. Int. Biodeterior. Biodegrad. 81, 88104.

[29] Pereira, M.O., Vieira, M.J., Melo, L.F., 2000. The effect of clay particles on the efficacy of a biocide. Water Sci. Technol. 41(4-5), 61-64.

[30] Raikos, V., Vamvakas, S.S., Sevastos, D., Kapolos, J., Karaiskakis, G., Koliadima, A., 2012. Water content, temperature and biocide effects on the growth kinetics of bacteria isolated from JP-8 aviation fuel storage tanks. Fuel. 93, 559-566.

[31] Rodríguez-Rodríguez, C.E., Rodríguez-Cavallini, E., Blanco, R., 2009. Bacterial contamination of automotive fuels in a tropical region: the case of Costa Rica. Revista de Biología Tropical. 57(3), 489-504.

[32] Schleicher, T., Werkmeister, R., Russ, W., Meyer Pittroff, R., 2009. Microbiological stability of biodiesel-diesel mixtures. Bioresour. Technol. 100(2), 724-730.

[33] Schwingel, W.R., Eachus, A.C., 2009. Antimicrobial additives for metalworking lubricants, in: Rudnick, L.R. (Ed.), Lubricant Additives: Chemistry and Applications, $2^{\text {nd }}$ ed. CRC, Boca Raton. 383-397.
[34] Siegert, W., 2009. Microbial contamination in diesel fuel-are new problems arising from biodiesel blends, in: IASH, $11^{\text {th }}$ International Conference on Stability. Handling and Use of Liquid Fuels, Prague, Czeth Republic. 18-22.

[35] Soriano, A.U., Martins, L.F., de Assumpção Ventura, E.S., de Landa, F.H.T.G., de Araújo Valoni, É., Faria, F.R.D., Ferreira, R.F., Faller, M.C.K., Valério, R.R., de Assis Leite, D.C., do Carmo, F.L., 2015. Microbial aspects of biodiesel and biodiesel/diesel blends biodeterioration. Int. Biodeterior. Biodegrad. 99, 102-114.

[36] Strömberg, N., Saramat, A., Eriksson, H., 2013. Biodiesel degradation rate after refueling. Fuel. 105, 301-305.

[37] Trafny, E.A., Lewandowski, R., Kozlowska, K., ZawistowskaMarciniak, I., Stepinska, M., 2015. Microbial contamination and biofilms on machines of metal industry using metalworking fluids with or without biocides. Int. Biodeterior. Biodegrad. 99, 31-38.

[38] Zimmer, A., Galves, F., Canal, N., Corção, G., Bento, F.M., 2010. Monitoramento da contaminação microbiana em tanque subterrâneo com diesel e biodiesel (B4) in: $4^{\circ}$ congresso da rede brasileira de tecnologia de biodiesel e $7^{\circ}$ congress brasileiro de plantas oleaginosas, óleos, gorduras e biodiesel, belo horizonte. Anais LAVRAS: UFLA. 3, 1505-1506.

[39] Zimmer, A., Bucker, F., Bento, F.M., Cavalcanti, E.H.S., Guillermo, H., Pacheco, J., Resende, V.L.D., Teixeira, R.M., Viscardi, S.L.C., 2012. Vida de prateleira e avaliação dos níveis de contaminação de diesel S500, biodiesel metílico de soja e de misturas B5 e B20 armazenados em recipientes de aço por 120 dias na região sul in: $5^{\circ}$ congresso da rede brasileira de tecnologia de biodiesel e $8^{\circ}$ congresso brasileiro de plantas oleaginosas, óleos, gorduras e biodiesel, Salvador. Anais LAVRAS: UFLA. 3, 1511-1512.

[40] Zimmer, A., Cazarolli, J., Teixeira, R.M., Viscardi, S.L.C., Cavalcanti, E.S.H., Gerbase, A.E., Ferrão, M.F., Piatnicki, C.M.S., Bento, F.M., 2013. Monitoring of efficacy of antimicrobial products during 60 days storage simulation of diesel (B0), biodiesel (B100) and blends (B7 and B10). Fuel. 112, 153-162. 